\section{Proge \\ SáencePark Research, Organization \& Counseling \\ Cypriot Journal of Educational Sciences}

Volume 13, Issue 1, (2018) 41-52

\section{CJES \\ 2004}

www.cjes.eu

\title{
High school students' metaphorical perceptions of biology and biology teacher concepts
}

Pınar Koseoglu*, Hacettepe University, Faculty of Education, EBB, Beytepe/ Ankara, 06800, Turkey. Hulya Pehlivan Hacettepe University, Faculty of Education, EBB, Beytepe/ Ankara, 06800, Turkey.

\section{Suggested Citation:}

Koseoglu, P., Pehlivan, H. (2018). High school students' metaphorical perceptions of biology and biology teacher concepts. Cypriot Journal of Educational Science. 8(1), 41-52.

Received date August 30, 2017; revised date November 30, 2017; accepted date December 29, 2017 Selection and peer review under responsibility of Prof Dr. Huseyin Uzunboylu Near East University. ${ }^{\circ} 2018$ SciencePark Research, Organization \& Counseling. All rights reserved.

\begin{abstract}
The purpose of the study was to identify and analyse high school students' metaphorical perceptions of biology and biology teacher concepts. The sample comprised all the 515 students studying in the Etimesgut district in Ankara in the spring semester of the 2015/2016 academic year. The data were gathered through a form which included the phrases 'Biology/the biology teacher is similar to/the same as..., because...' The data for the research were collected through qualitative research methods. The research approach adopted was phenomenological. Content analysis was used for the data analysis. According to the results, high school students use different metaphors to describe the biology concept. These metaphors are united under different conceptual categories in terms of their common qualities. The study results show how metaphors can be used as an important research tool in understanding and explaining the perceptions of students towards biology and biology teacher.
\end{abstract}

Keywords: Biology, biology teacher, metaphor, metaphoric thought, phenomenological research.

* ADDRESS FOR CORRESPONDENCE: Pınar Koseoglu*, Hacettepe University, Faculty of Education, EBB, Beytepe/ Ankara, 06800, Turkey. E-mail address: koseoglup@gmail.com / Tel.: +90 31229768 20-21. 
Koseoglu, P., Pehlivan, H. (2018). High school students' metaphorical perceptions of biology and biology teacher concepts. Cypriot Journal of Educational Science. 8(1), 41-52.

\section{Introduction}

Biology - the science of living organisms-is a branch of science which obtains information on the life, development and change of living organisms and their relationships with each other on earth, which adds to information enabling analysis and research on the earth, the living environment of those living things. This serves the public good in association with other branches of science which keeps changing (Parlak, 2007). Observation is the starting point for biology (Tunnicliffe \& Ueckert, 2011) and because the science of biology studies living organisms and their relationships with the environment, it is a science with both scientific and social aspects (Yalmanci \& Aydin, 2013). It came into existence as a result of man's need to recognise and understand creatures in nature and to use, modify and make them beneficial to humans in accordance with their needs (Sulun, 2002). Thus, detailed knowledge of biology is needed and it is important for students to understand the concept of biology correctly. Students' conceptions of the teaching and learning of biology are that 'teaching biology is an interactive and lecture-based process' and 'learning biology is a visual process' (Subramaniam, 2014). Metaphors are the most effective instrument that can be used to discover students' perceptions of the concept of biology.

Metaphor is used when one wishes to comprehend or to describe something that is difficult to understand, abstract or highly speculative (Yob, 2003). Metaphors, according to Lakoff and Johnson (1980), help us to understand what is happening around us and to detail our experiences. Lakoff and Johnson (2005) state that the use of a metaphor is the process of describing something from the perspective of something else and experiencing it and expressing the material of a thought in a form of human comprehension. Metaphors are conceptual configurations and they are also at the centre of cognitive and intellectual development (Hongqin \& Jianbin, 2008). Moreover, the majority of our conceptual system is composed of metaphorical relations (Martinez, Sauleda \& Huber, 2001). Consequently, metaphors provide a way of understanding life; they regulate our experiences and they may be said to help us to understand what is happening around us.

When seen from the perspective of education, it is possible to benefit from metaphors in planning, in curriculum development and in encouraging learning. The benefits of using metaphors in education include the following: a) they connect two objects or concepts, b) they make comparisons, c) they are useful instruments for learning and they raise motivation, d) they ensure that knowledge remains in the mind, e) they can develop intuitions and can improve emotional development, f) they eliminate the fear of grade levels and unwillingness to learn, $g$ ) they ensure creative and discovery learning and h) they develop imagination (Semerci, 2007). Metaphors also ensure the capture of affective schemata which are the sources of emotions too strong for individuals to express and thus, they make it possible to transmit the message in words with no loss in effect and they function as mental instruments providing researchers in education and linguists with important pedagogical information (Zeren, 2015). The reason for this is that, as Erdem, Bulbul, Gun and Oran (2015) point out, metaphorical thinking has great importance in identifying individuals' world views and making sense of the world as well as in their communication concerning work, phenomena, concepts, subjects and objects.

Metaphors were accepted as a method in scientific studies following the 1980s and became the subject matter of many studies. The relevant literature shows that there are studies (Zeren, 2015) analysing the metaphorical perceptions of secondary school students, university students, pre-service and in-service teachers concerning such concepts and phenomena as teachers (Akinoglu \& Eren, 2016; Ben-Peretz, Mendelson \& Kron, 2003; Boulton, Grauer \& Irwin, 2016; Boyd \& Bloxham, 2014; Cerit, 2008; Farrell, 2006; Goldstein, 2005; Gur, 2012; Leavy, McSorleya \& Bote, 2007; Polat, Apak \& Akdag, 2013; Saban, Kocbeker \& Saban, 2006; Tait-McCutcheon \& Drake, 2016), students (Brookes \& Etkina, 2007; Guner, 2012; Koc, 2013; Saban, 2009; Wang \& Xu, 2006), schools (Aydogdu, 2008; Balci, 2011; Demir, 2007; Hoffman \& Kretovics, 2004; Ozdemir, 2012; Swaffield, 2014), course books (McGrath, 2006), classroom management (Akar \& Yildirim, 2009; Orucu, 2012; Uysal, Firdevs, Tepetas \& Akman, 
2014), teaching (Alger, 2009; Niebert \& Gropengiesser, 2015; Shaw, Massengill \& Mahlios, 2008; Wegner \& Nuckles, 2015) and learning (Eren \& Tekinarslan, 2013; Stylianou, Kulinna, Cothran \& Kwon, 2013; Zheng, 2008). Metaphor studies in the field of biology and biology education are also addressed in our research. Metaphors related to the concept of the environment (Aydin, 2011; KoptjevskajaTamm \& ljzerman, 2015), the concept of biology (Beger \& Jakel, 2015; Yalmanci \& Aydin, 2013; Petkov, 2012; Ulukok, Bayram \& Selvi, 2015), the concept of the 'genome' (Andrzej, 2002), the concepts of the greenhouse effect, the ozone layer, acid rain and biological diversity (Selvi, 2007) and the concept of synthetic biology (Hellsten \& Nerlich, 2011) are available in the literature. Apart from these, studies performed by Yalmanci and Aydin (2013) and by Yapici (2015) in the field of biology have also contributed to the field. Nevertheless, it is clear that there are still only few studies concerning metaphorical perceptions in the field of biology. Therefore, it is thought that this study will contribute to research on perceptions of biology and biology teachers.

\subsection{Sub-problems}

This study aims to examine high school students' perceptions of the concepts of 'biology' and 'biology teacher' through metaphors. Within the scope of this general purpose, answers are sought to the following questions:

1. Through what metaphors, do high school students describe their perceptions of the concepts of 'biology' and 'biology teacher'?

2. Into what conceptual categories can the metaphors used by high school students for the concepts of 'biology' and 'biology teacher' be divided according to their common properties?

\section{Method}

\subsection{Research design}

This research employed a phenomenological design, qualitative research methods to analyse the metaphors that high school students created to express their perceptions of the concepts of 'biology' and 'biology teacher'. The data were then subjected to content analysis. A phenomenological design focuses on the phenomena of which we are aware but do not understand in depth and in detail. Phenomenology forms an appropriate basis for studies aiming to research phenomena which are not completely unfamiliar to us and yet the meaning of which we do not fully understand (Yildirim \& Simsek, 2008).

\subsection{Study group}

The study group included 515 high school students, 204 of whom were female and 311 male, studying in the Etimesgut district of Ankara in the 2015/2016 academic year.

\subsection{Data collection}

The research data were collected in the autumn semester of the 2015/2016 academic year. Prospective teachers were given a form containing semi-structured questions in order to determine their perceptions of the concepts of 'biology' and 'biology teacher'. They were asked to complete the sentence 'Biology/the biology teacher is like ... because ...' The participants needed to express their thoughts by concentrating on only one metaphor. No comments were made to avoid misleading the participants. 


\subsection{Data analysis and interpretation}

Content analysis was employed to analyse the data. The purpose of content analysis is to identify concepts and relationships capable of explaining the data. The first four stages followed by other researchers (Aydin \& Unaldi, 2010; Saban, 2008; Yapici, 2015) were adopted in undertaking the content analysis. The stages of the content analysis were as follows: 1) coding and sorting out, 2) compiling sample metaphors, 3) categorising, 4) attaining validity and reliability; The agreements and disagreements between the researcher and the expert were taken into consideration and using Miles and Huberman's (1994) formula of reliability = agreement/agreement + disagreement, reliability was found to be 0.95 for the concept of 'biology', 0.93 for the concept of 'biology teacher' and 0.90 for 'three things that biology brings to mind'. The desired level of reliability is reached in qualitative research when agreement between the expert and the researcher is $90 \%$ or above (Saban, Kocbeker \& Saban, 2006) and 5) transferring the data to the computer medium. In addition, a map of codes was created for the data using the qualitative data analysis programme MAXQDA 12.

\section{Findings}

This section presents the findings concerning the research questions, discussing the metaphors created by high school students following the analysis of the questionnaire forms. The conceptual categories formed according to the shared properties of the metaphors are then shown, together with examples from the students' responses. Table 1 shows the metaphors created by high school students in relation to the concept of 'biology'.

Table 1. Metaphors created by high school students in relation to the concept of 'biology'

\begin{tabular}{|c|c|c|c|}
\hline Categories & Biology is like ... because ... & Frequency & Percentage (\%) \\
\hline $\begin{array}{l}\text { Biology as the source and } \\
\text { domain of life }\end{array}$ & $\begin{array}{l}\text { Life (98), nature (28), human (20), food } \\
(15) \text {, living thing (10), water ( } 7) \text {, universe } \\
(5) \text {, sea (5), world (4), light (4), cell (3), } \\
\text { animal (3), brain (3), body (3), space (3), } \\
\text { ocean (2), organ (2), breathing (2), rainbow } \\
\text { (2), cell nucleus (1), skeleton (1), scenario } \\
\text { of animation (1), self-recognition (1), child } \\
(1), \text { heart (1), the sun (1) }\end{array}$ & 226 & 43.9 \\
\hline Biology as a need & $\begin{array}{l}\text { Necessity (3), key (2), sleep (2), health (1), } \\
\text { road (1) }\end{array}$ & 9 & 1.7 \\
\hline Biology as science & $\begin{array}{l}\text { Course (59), science (20), book (6), } \\
\text { knowledge (5), medicine (4), microscope } \\
\text { (3), research (2), experiment (2), bioenergy } \\
\text { (1), school (1), hospital (1), time (1), trial } \\
\text { and error (1), dimension (1) }\end{array}$ & 107 & 20.7 \\
\hline $\begin{array}{l}\text { Biology as something } \\
\text { incomprehensible/intolerable }\end{array}$ & $\begin{array}{l}\text { Difficult (18), boring (13), bad (9), } \\
\text { unnecessary (7), complex (8), } \\
\text { memorisation (6), torment (4), disgusting } \\
\text { (4), guest's child (3), disease (3), formula } \\
\text { (2), foreign language (2), code (2), } \\
\text { Matryoshka doll (2), incomprehensible (1), } \\
\text { chaos (1), nightmare (1), prison (1), } \\
\text { garbage (1), dust particle (1), machine (1), } \\
\text { documentary (1) }\end{array}$ & 91 & 17.7 \\
\hline
\end{tabular}


Biology as an emotional
statement

Biology as a source of entertainment

No answer

TOTAL
Good (14), love (3), extraordinary (1), enjoyable (1), unique (1), imagination (1), miracle (1)

Football team (7), music (3), game (2), art

(2), jigsaw (1), Lego (1), enjoyable (1),

basketball (1), film (1)

Unanswered (33) and invalid (8)
22

4.3

3.7

19

41

515
8.0

100

According to Table 1, 515 responses in total were obtained for high school students' concept of biology, 33 of them not answering the question. Although the great majority of the metaphors offered were positive, a small part of them were negative.

The categories constituted from the metaphors created by high school students are given in Figure 1.

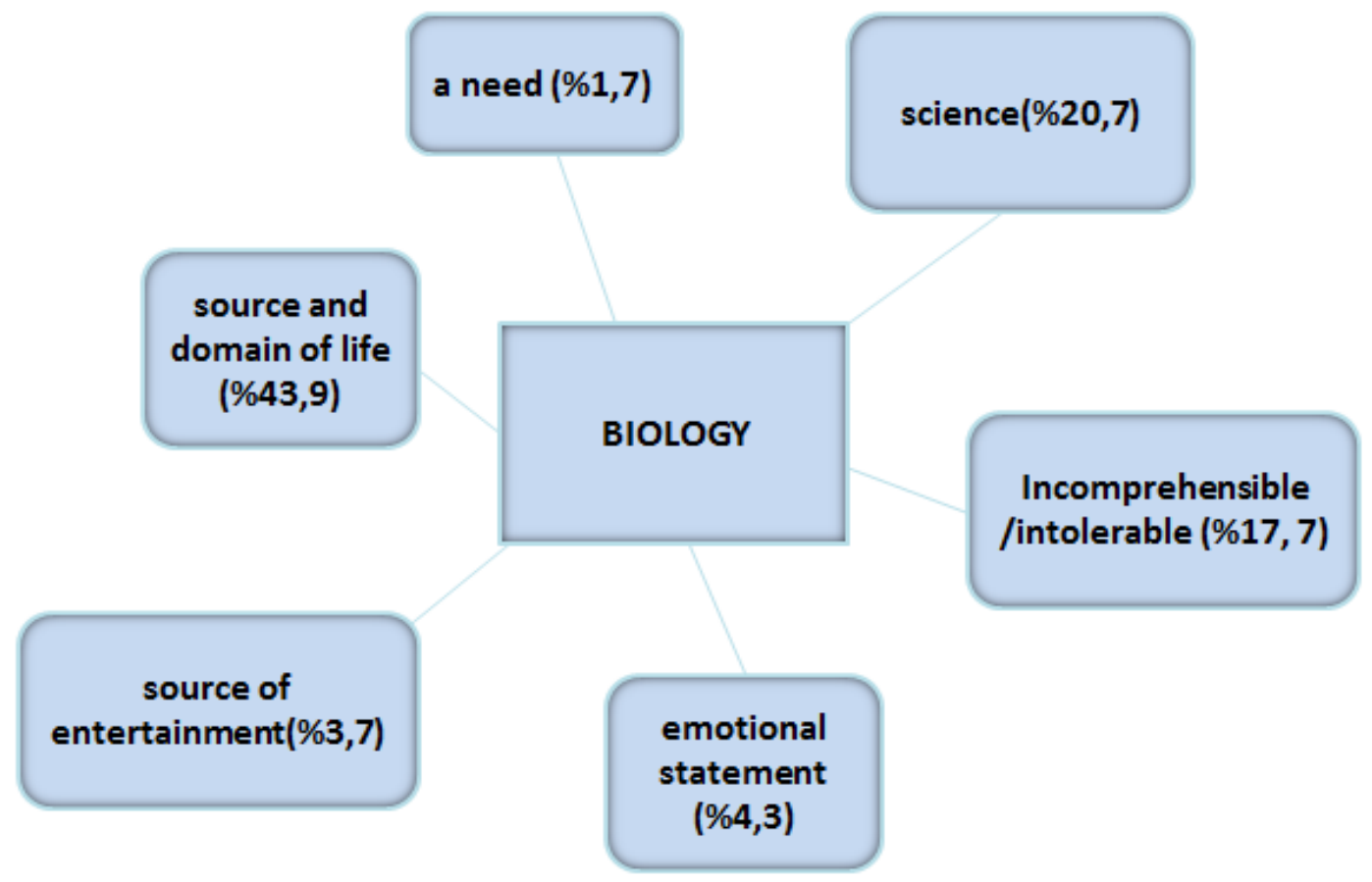

Figure 1. Categories formed by the metaphors created by high school students

Biology as the source and domain of life: Some of the statements in this category were as follows:

'Biology is like life because it describes the animation and art of life'.

'Biology is like nature because there are a lot of colourful topics in it'.

Biology as a need: Some of the statements in this category were as follows:

'Biology is a necessity because it occupies an important place in human life'.

'Biology is like sleep because it assures looking at the realities of life from a different perspective'.

Biology as science: Some of the statements in this category were as follows:

'Biology is like a course because it always contains diverse topics'. 
'Biology is like a science because we can only see to the horizon but the reality is well beyond it'.

Biology as incomprehensible/intolerable: Some of the statements in this category were as follows:

'Biology is difficult because it is memorisation'.

'Biology is boring because it makes me sleepy'.

Biology as an emotional statement: Some of the statements in this category were as follows:

'Biology is good because it leads us into the right way'.

'Biology is love because you love it more as you love'.

Biology as a source of entertainment: Some of the statements in this category were as follows:

'Biology is like a football team because it is everywhere in our life'.

'Biology is like music because it causes addiction'.

Table 2. Metaphors created by high school students in relation to the concept of 'biology teacher'

\begin{tabular}{|c|c|c|c|}
\hline Categories & Biology is like ... because ... & Frequency & Percentage (\%) \\
\hline $\begin{array}{l}\text { Biology teacher as } \\
\text { the source of life }\end{array}$ & $\begin{array}{l}\text { Food (11), life (9), human (8), water (6), phlegm } \\
(5) \text {, cells and organelles (5), family (3), tree (3), } \\
\text { bee (2), the sun (2), animal (2), source of life } \\
\text { (2), soil and oxygen (1), body (1), root of living } \\
\text { things (1), nature (1), breath (1), seed (1), } \\
\text { carotid (1), rain (1) }\end{array}$ & 66 & 12.8 \\
\hline $\begin{array}{l}\text { Biology teacher as } \\
\text { guide and leader }\end{array}$ & $\begin{array}{l}\text { Book (19), scientist (12), scholar (8), guide (6), } \\
\text { explanatory (4), life assistant (3), life coach ( } 3 \text {, } \\
\text { light (3), someone describing living things fully } \\
\text { (3), a brain box (3), professor (3), map maker } \\
\text { (2), guide (2), advisor (2), source of knowledge } \\
\text { (3), biologist (3), library (2), school (2), boss (2), } \\
\text { illuminator (1), master (1), road (1), path finder } \\
\text { (1), hero (1), sermoniser (1), dictionary (1), } \\
\text { search engine (Google) (1) }\end{array}$ & 94 & 18.3 \\
\hline $\begin{array}{l}\text { Biology teacher as a } \\
\text { need }\end{array}$ & $\begin{array}{l}\text { Teacher (65), doctor (37), mother (14), friend } \\
(4), \text { pal (3), elder sister (2), lesson (2) }\end{array}$ & 127 & 24.7 \\
\hline $\begin{array}{l}\text { Biology teacher as } \\
\text { one who is } \\
\text { incomprehensible/in } \\
\text { tolerable }\end{array}$ & $\begin{array}{l}\text { Making sleepy (11), memoriser (3), chatterer } \\
\text { (3), nightmare (2), obligatory (2), an } \\
\text { undecipherable code (1), governor of a jail (1) }\end{array}$ & 23 & 4.5 \\
\hline $\begin{array}{l}\text { Biology teacher as an } \\
\text { emotional statement }\end{array}$ & $\begin{array}{l}\text { Good (55), flower (17), angry (11), angel (9), } \\
\text { bad (2), love (1), unique (1), full of love (1), } \\
\text { super (1), luck (1), poem (1) }\end{array}$ & 100 & 19.4 \\
\hline No answer & Unanswered (37) and invalid (68) & 105 & 20.4 \\
\hline TOTAL & & 515 & 100 \\
\hline
\end{tabular}

According to Table 2, 515 responses in total were obtained for high school students' concept of biology teacher; 37 of them failed to answer the question and the metaphors created by 68 students were considered invalid. The categories constituted from the metaphors created by high school students are given in Figure 2. 


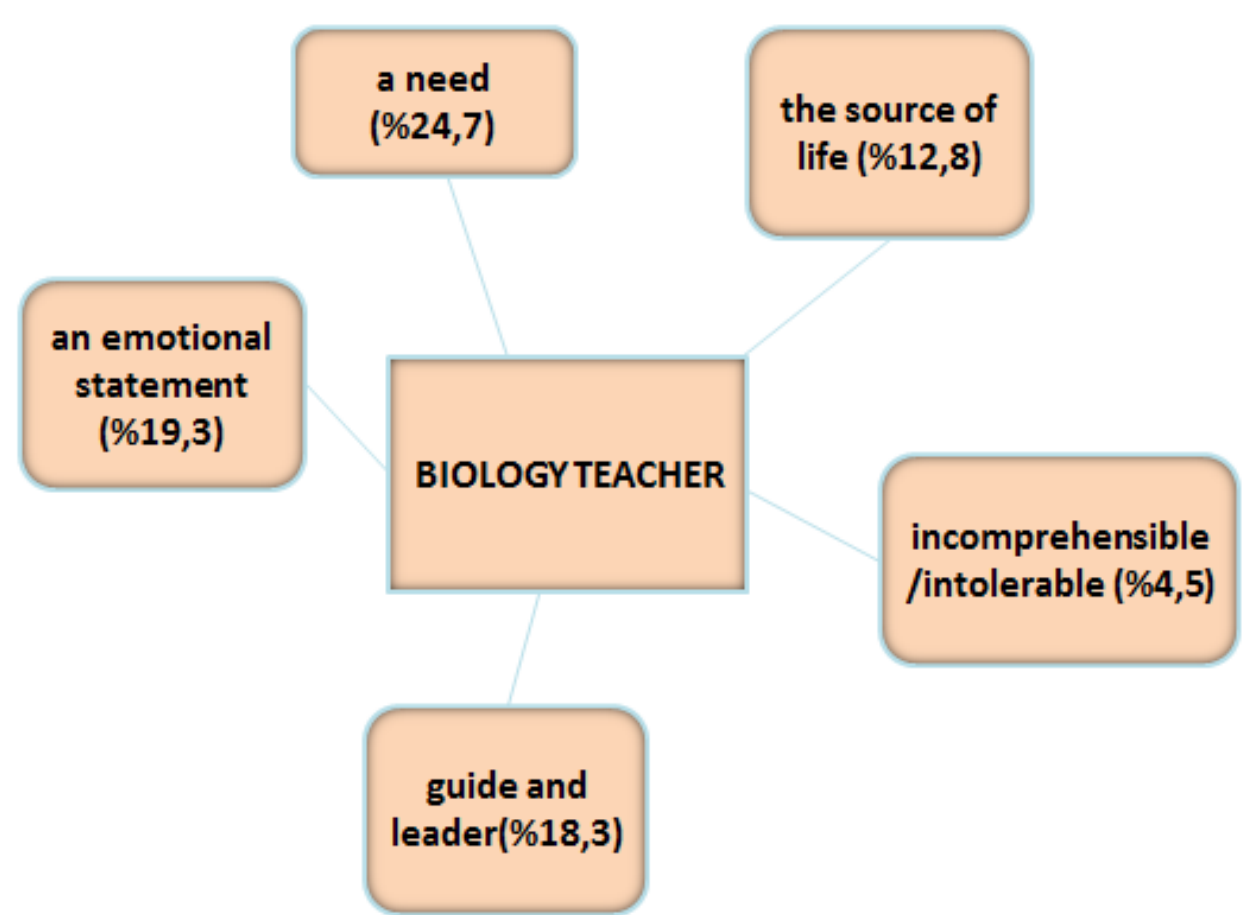

Figure 2. Categories formed by the metaphors created by high school students

Biology teacher as the source of life: Some of the statements in this category were as follows:

'A biology teacher is like food because he/she is sweet'.

'A biology teacher is like life because he/she is helpful in studying living things'.

Biology teacher as guide and leader: Some of the statements in this category were as follows:

'A biology teacher is like a book because we learn something different on each page'.

'A biology teacher is like a scientist because he/she makes experiments for us and informs us'.

Biology teacher as a need: Some of the statements in this category were as follows:

'A biology teacher is like a teacher because he/she teaches us everything'.

'A biology teacher is like a doctor because he/she knows a lot about living organisms'.

Biology teacher as incomprehensible/intolerable: Some of the statements in this category were as follows:

'A biology teacher is like something that makes us sleepy because he/she speaks too slowly while teaching, like a lullaby, and it makes us sleep'.

'A biology teacher is like a memoriser because he/she obliges us to memorise things'.

Biology teacher as an emotional statement: Some of the statements in this category were as follows:

'A biology teacher is like a flower because there is a different scent and a different image on each side'.

'A biology teacher is like an angel because he/she is a very good person and tells us'. 
Koseoglu, P., Pehlivan, H. (2018). High school students' metaphorical perceptions of biology and biology teacher concepts. Cypriot Journal of Educational Science. 8(1), 41-52.

\section{Conclusions and discussion}

This is a qualitative research study aiming to illustrate high school students' perceptions of 'biology' and 'biology teacher' through metaphors. The 515 high school students participating in the research were asked to complete the sentence 'biology/the biology teacher is like ... because ...' From the analyses, six categories were formed in relation to the concept of biology: biology as the source and domain of life, biology as a need, biology as science, biology as incomprehensible/intolerable, biology as an emotional statement and biology as a source of entertainment. These results were parallel and similar to those obtained by Yapici (2015). The terms used in biology are both difficult and boring for the students (Moses, 2013). There were students who found biology difficult (18), boring (13), bad (9) and unnecessary (7), but they were a minority. However, most students considered biology to be positive, as in Ulukok et al.'s (2015) study. The majority of those who considered biology to be positive associated it with such positive concepts as life (98), humans (20), nature (28), course (59) and science (20). Yalmanci and Aydin's (2013) study found 'life' to the most common (23.1\%) metaphor for biology, in parallel with this research (19\%). As is commonly known, biology is the science of animate beings and is concerned with such issues as nature, living organisms, life and the environment. In this respect, biology may be said to be the science closest to humans (Yetkin, 2000), ensuring that they recognise and decipher themselves and that they live accordingly. The results obtained also show that students make appropriate associations for the essence of the concept of biology.

In this study, students were asked to describe biology teachers within the framework of the sentence 'a biology teacher is like ... because ...' and it was found that the students described biology teachers in five categories: the biology teacher as the source of life, the biology teacher as a guide and leader, the biology teacher as a need, the biology teacher as incomprehensible/intolerable and the biology teacher as an emotional statement. Biology teachers were mostly described under the categories of guide and leader (27) and the source of life (20). In all, 72 metaphors were created in relation to the concept of the biology teacher. According to Table 2, there are negative descriptions of biology teachers, as in making sleepy (11), memoriser (3) and chatterer (3), as well positive descriptions, such as teacher (65), doctor (37), mother (14), food (11), book (19), scientist (12), good (55), flower (17) and angel (9). Clearly, there are more positive descriptions than negative as also obtained by Nikitina and Furuoka (2008) concerning teachers. These findings demonstrate that students primarily associate biology teachers with 'teachers', 'doctors' and 'mothers' -all of whom are needed in humanitarian situations and in various circumstances. Descriptions in the form of 'book' and 'scientist' are important in that they perceive biology teachers as a source of reference, consulting and benefitting from their knowledge in an academic sense.

While students are associated with $17.7 \%$ of negatives in biology-related metaphors, the negative metaphors of biology teachers are only $4.5 \%$. Thus, we can say that students love biology teachers even when they do not like biology. Teachers' personalities shape students perceptions, values, beliefs and principles about teaching (Richardson, 1996; Dhindsa, 2008). The attitudes of students towards biology teachers are strongly affected by their teacher identity (Prokop, Tuncer \& Chuda, 2007). The teacher-student interactions reflect the general image of the youth-elder relationship in society (Lee, Fraser \& Fisher, 2003).

The metaphors use in biology teaching possibly affords cognitive change and hence, it is likely to further enhance the students' understanding of the respective scientific concepts (Beger \& Jakel, 2015). The primary function of metaphors is to provide a conceptual framework and supply common explanation, of complex and heterogeneous phenomena in biology education (Petkov, 2012). When the metaphors obtained from the research are examined, it can be said that the perceptions of the students concerning biology are positive. Ben-Peretz et al. (2003) stated that metaphorical images created by metaphor perceptions can be used as a research and teaching tool in education programmes. Therefore, materials that will be prepared by using positive metaphors for students will strengthen the positive perceptions of students in biology education. 
Koseoglu, P., Pehlivan, H. (2018). High school students' metaphorical perceptions of biology and biology teacher concepts. Cypriot Journal of Educational Science. 8(1), 41-52.

\section{References}

Akar, H. \& Yildirim, A. (2009). Change in teacher candidades' metaforical images about classroom management in a social constructivist learning environment. Teaching in Higher Education, 4(14), 401-415.

Akinoglu, O. \& Eren, C. D. (2016). Comparison of pre-service teachers' metaphors regarding the concept of "scientific knowledge". Education, 30(58), 11-21.

Alger, C. (2009). Secondary teachers' conceptual metaphors of teaching and learning: changes over the career span. Teahing \& Teacher Education: An International Journal of Research and Studies, 25(5), 743-751.

Andrzej, K. K. (2002). Grand metaphors of biology in the genome era. Computers \& Chemistry, 26(5), 397-401.

Aydin, F. \& Unaldi, U. E. (2010). Cografya ogretmen adaylarinin "Cografya" kavramina iliskin algilarinin metaforlar yardimiyla analizi [Analysis of the candidates of the geography teacher candidates with the help of metaphors of the "Geography" conceptual intellectual perceptions]. International Online Journal of Educational Sciences, 2(2), 600-622.

Aydin, F. (2011). Universite ogrencilerinin "cevre kavramina iliskin metaforik algilari [Metaphorical perceptions of the environmental concept of the university students]. Dogu Cografya Dergisi, 26, 25-44.

Aydogdu, E. (2008). Ilkogretim okullarındaki ogrenci ve ogretmenlerin sahip olduklari okul algilari ile ideal okul algilarinin metaforlar yardimiyla analizi[Metaphorical analysis of school perceptions and ideal school perceptions of students and teachers in primary schools] (Unpublished master's thesis). Eskisehir Osmangazi Universitesi Fen Bilimleri Enstitusu, Eskisehir, Turkey.

Balci, F. A. (2011). Metaphorical images of school: school perceptions of primary education supervisors. Eurasian Journal of Educational Research, 44, 51-70.

Beger, A. \& Jakel, O. (2015). The cognitive role of metaphor in teaching science: examples from physics, chemistry, biology, psychology and philosophy. Philosophical Inquiries, 3(1), 89-112.

Ben-Peretz, M., Mendelson, N. \& Kron, F. W. (2003). How teachers in different educational contexts view their roles. Teaching \& Teacher Education, 19, 277-290.

Boulton, A., Grauer, K. \& Irwin, R. L. (2016). Becoming teacher: a/r/tographical inquiry and visualising metaphor. International Journal of Art \& Design Education, 36(2), 200-214.

Boyd, P. \& Bloxham, S. (2014). A situative metaphor for teacher learning: the case of university tutors learning to grade student coursework. British Educational Research Journal, 40, 337-352. doi:10.1002/berj.3082.

Brookes, D. T. \& Etkina, E. (2007). Using conceptual metaphor and functional grammar to explore how language used in physics affects student learning. Physical Review Physics Education Research, 3(010105), 1-16.

Cerit, Y. (2008). Ogretmen kavrami ile ilgili metaforlara iliskin ogrenci, ogretmen ve yoneticilerin gorusleri [Teachers, teachers and administrators' views on the metaphor related to the concept of teacher]. Turk Egitim Bilimleri Dergisi, 6(4), 693-712.

Demir, C. E. (2007). Metaphors as a reflection of middle school students' perceptions of school: a cross-cultural analysis. Educational Research and Evaluation, 13(2), 89-107.

Dhindsa, H. S. (2008). Cultural dimensions of the learning environment in Brunei. International Journal of Science and Mathematics Education, 6(2), 251-267.

Erden, M. (1998). Ogretmenlik meslegine giris. Istanbul, Turkey: Alkim Yayinlari.

Erdem, M. D., Bulbul, T., Gun, M. \& Oran, G. (2015). Ortaokul ogrencilerinin turkce dersine iliskin algilarinin metaforlar araciligiyla belirlenmesi [Determination of the relative perception of secondary school pupils to Turkish lessons through metaphors]. Jedus, 2(2), 50-63.

Eren, A. \& Tekinarslan, E. (2013). Prospective teachers' metaphors: teacher, teaching, learning, instructional material and evaluation concepts. International Journal of Social Sciences and Education, 3(2), 435-445.

Farrell, T. S. C. (2006). 'The teacher is an octopus' uncovering preservice english language teachers' prior beliefs through metaphor analysis. A Journal of Language Teaching and Research, 37(2), 236-248.

Gillis, C. \& Johnson, C. L. (2002). Metaphor as renewal: re-imagining our professional selves. The English Journal, 91(6), 37-43.

Goldstein, L. S. (2005). Becoming a teacher as a hero's journey: using metaphor in preservice teacher education. Teacher Education Quarterly, 32(1), 7-24. 
Guner, N. (2012). Using metaphor analysis to explore high school students' attitudes towards learning mathematics. Ingenta Connect, 1, 39-48.

Gur, H. (2012). Ogretmen adaylarinin ogretmen ve ogretmenlik meslegi ile ilgili metaforlari: Kosova ornegi [Metaphor for teacher candidates' teaching and teaching profession: the Kosovo example]. New World Sciences Academy NWSA-Education Sciences, 1C0552, 7(3), 885-897.

Gurbuzoglu, S. \& Aydin, S. (2014). Ogretmen adaylarinin kopya cekmeye yonelik metaforik algilari [Metaphorical perception of teacher candidates' motivation to copy]. Erzincan Universitesi Egitim Fakultesi Dergisi, 16(1), 316-332.

Hellsten, L. \& Nerlich, B. (2011). Synthetic biology: building the language for a new science brick by metaphorical brick. New Genetics \& Society, 30(4), 375-397.

Hongqin, Z. \& Jianbin, H. (2008). Interpreting metaphor in use by mandarin teachers of english. Polyglossia, 15, $1-9$.

Hoffman, K. D. \& Kretovics, M. A. (2004). Students as partial employees: a metaphor for the student-institution interaction. Innovative Higher Education, 29(2), 103-120.

Koc, M. (2013). Student teachers' conceptions of technology: a metaphor analysis. Computers \& Education, 68, $1-8$.

Koptjevskaja-Tamm, M. \& ljzerman, H. (2015, September 2-5). How our biology predisposes us to an "Affection is Warmth" "metaphor", and how our environment changes its anchor. In 48th Annual Meeting of the Societas Linguistica Europea (pp. 83-84). Leiden, The Netherlands.

Lakoff, G. \& Johnson, M. (1980). Metaphors we live by. Chicago, IL: University of Chicago Press.

Lakoff, G. \& Johnson, M. (2005). Metaforlar: hayat, anlam ve dil [Metaphors: life, meaning and language] (G. Y. Demir, Trans.). Istanbul, Turkey: Paradigma.

Leavy, A. M., McSorleya, F. A. \& Bote, L. A. (2007). An examination of what metaphor construction reveals about the evolution of preservice teachers' beliefs about teaching and learning. Teaching and Teacher Education, 23(7), 1217-1233.

Lee, S. S., Fraser, B. J. \& Fisher, D. L. (2003). Teacher-student interactions in Korean high school science classrooms. International Journal of Science and Mathematics Education, 1(1), 67-85.

Martinez, M. A., Sauleda, N. \& Huber, G. L. (2001). Metaphors as blueprints of thinkking about teaching and learning. Teaching and Teacher Education, 17, 965-977.

McGrath, I. (2006). Teahers' and learners' images for coursebooks. ELT Journal, 60(2), 171-180.

Miles, M. B. \& Huberman, A. M. (1994). Qualitative data analysis. Thousand Oaks, CA: Sage.

Moses, M. (2013). Biology topics perceived as different by high school pupils of Kasama and Mungwi districts of Zambia (Unpublished master's thesis). University of Zambia, Lusaka, Zambia.

Niebert, K. \& Gropengiesser, H. (2015). Understanding starts in the mesocosm: conceptual metaphor as a framework for external representations in science teaching. International Journal of Science Education, 37(56), 903-933.

Nikitina, L. \& Furuoka, F. (2008). A language teacher is like: examining Malaysian students' perceptions of language teachers through metaphor analysis. Electronic Journal of Foreign Language Teaching, 5(2), 192205.

Orucu, D. (2012). Ilkogretim sinif ogretmenlerinin sinifa ve sinif yonetimine iliskin metaforik bakislari: Karsilastirmali bir durum calismasi [Relevant metaphorical overviews of classroom classroom teachers to classroom and classroom management: a comparative case study]. Ilkogretim Online, 11(2), 342-352.

Ozdemir, M. (2012). Lise ogrencilerinin metaforik okul algilarinin cesitli degiskenler bakimindan incelenmesi [Investigation of high school students' metaphorical school perceptions in terms of various variables]. Egitim ve Bilim, 37(163), 96-109.

Parlak, N. (2007). 2000-2006 yillari arasinda ogrenci secme sinavinda cikan biyoloji sorularinin konulara gore dagilimi ve orta ogretimden yuksek ogretime geciste biyoloji ozelinde yasanan sorunlar[Between the years of 2000-2006, student's choice of questions on the topic of gonorrhoeae biology questions gore distribution and middle education to high school graduate biology] (Unpublished master's thesis). Gazi Universitesi Egitim Bilimleri Enstitusu, Ankara, Turkey. 
Petkov, S. (2012). Metaphors in science: the presence of the relief metaphor in evolutionary biology. Philosophical Alternatives Journal/Filosofski Alternativi, 21(1), 79-89.

Polat, S., Apak, O. \& Akdag, M. (2013). Sinif ogretmeni adaylarinin akademisyen kavramina iliskin algilarinin metafor analizi yoluyla incelenmesi [Examination of classroom teacher candidates through metaphor analysis of academicians' conceptual intellectual perceptions]. Inonu Universitesi Egitim Fakultesi Dergisi, 14(2), 5778.

Prokop, P., Tuncer, G. \& Chuda, J. (2007). Slovakian students' attitudes toward biology. Eurasia Journal of Mathematics, Science \& Technology Education, 3(4), 287-295.

Richardson, V. (1996). The role of attitudes and beliefs in learning to teach. Handbook of research on teacher education, 2, 102-119.

Saban, A. (2008). Primary school teachers' and their students' mental images about the concept of knowledge. Elementary Education Online, 7(2), 421-455.

Saban, A. (2009). Ogretmen adaylarinin ogrenci kavramina iliskin sahip olduklari zihinsel imgeler [Teacher candidates possessing the student conceptual relationship have mental imagery]. Turk Egitim Bilimleri Dergisi, 7(2), 281-326.

Saban, A., Kocbeker, B. A. \& Saban, A. (2006). An investigation of the concept of teacher among prospective teacher among prospective teachers through metaphor analysis. Educational Sciences: Theory \& Practices, $6(2), 509-522$.

Semerci, C. (2007). "Program Gelistirme" Kavramina iliskin metaforlarla yeni ilkogretim kavramina farkli bir bakis ["Program Development" A different perspective on conceptualization of new primitive concepts with related metaphors]. C.U. Sosyal Bilimler Dergisi, 31(2), 125-140.

Selvi, M. (2007). Biyoloji ogretmen adaylarinin cevre kavramlari ile ilgili algilamalarinin degerlendirilmesi [Assessing the perceptions of biology teacher candidates about their environmental concepts] (Unpublished doctoral dissertation). Gazi Universitesi, Ankara, Turkey.

Shaw, D., Massengill, B. \& Mahlios, M. (2008). Preservice teachers' metaphors of teaching in relation to literacy beliefs. Teachers and Teaching: Theory and Practice, 14(1), 35-50.

Stylianou, M., Kulinna, P. H., Cothran, D. \& Kwon, J. Y. (2013). Physical education teachers' metaphors of teaching and learning. Journal of Teaching in Physical Education, 32(1), 22-45.

Swaffield, S. (2014). Support and challenge for school leaders Headteachers' perceptions of school improvement partners. Educational Management Administration \& Leadership, 43(1), 61-76.

Subramaniam, K. (2014). Student teachers' conceptions of teaching biology. Journal of Biological Education, 48(2), 91-97.

Sulun, A. (2002). Universite secme sinavlarinda yoneltilen biyoloji sorularinin orta ogretim biyoloji ogretim programiyla uygunlugu ve bu alandaki basarisizligin sebepleri [The relevance of biology questions directed at university selection examinations to the secondary school biology curriculum and the reasons for this failure] (Unpublished doctoral dissertation). Ataturk Universitesi, Fen Bilimleri Enstitusu, Erzurum, Turkey.

Tait-McCutcheon, S. \& Drake, M. (2016). If the jacket fits: a metaphor for teacher professional learning and development. Teaching and Teacher Education, 55, 1-12.

Tunnicliffe, S. D. \& Ueckert, C. (2011). Early biology: the critical years for learning. Journal of Biological Education, 45(4), 173-175.

Ulukok, S., Bayram, K. \& Selvi, M. (2015). Pre-service science teachers' mental images towards biology concept (metaphor analysis sample). International Online Journal of Educational Sciences, 7(3), 244-259.

Uysal H., Firdevs B., Tepetas, G. S. \& Akman, B. (2014). Preschool education and primary school pre-service teachers' perceptions about classroom management: a metaphorical analysis. International Journal of Instruction, 7(2), 165-180.

Wang, F. X. \& Xu, Q. L. (2006). A metaphorical approach to the study of English major's belief system. Journal of Sichuan College of Education, 22(7), 38-71.

Wegner, E. \& Nuckles, M. (2015). Knowledge acquisition or participation in communities of practice? academics' metaphors of teaching and learning at the university. Studies in Higher Education, 40(4), 624-643. 
Yalmanci, S. \& Aydin, S. (2013). Ogretmen adaylarinin biyoloji kavramina iliskin metaforik algilari [Metaphorical perceptions of the biology concept of prospective teacher candidates]. Mustafa Kemal Universitesi Sosyal Bilimler Enstitusu Dergisi, 10(21), 208-223.

Yapici, I. U. (2015). Lise ogrencilerinin biyolojiye yonelik meteforik algilari [Metaphoric perceptions of high school students towards biology]. Elektronik Sosyal Bilimler Dergisi, 14(55), 139-147.

Yetkin, Y. (2000). Biyoloji egitimi, ogretimi ve ogretmen yetistirilmesinde yeni yaklasimlar: biyoloji felsefe ve mantiginin anlasilmasi [New approaches in biology education, teaching and teacher training: understanding biology philosophy and logic] (pp. 51-57). IV. Fen Bilimleri Egitimi Kongresi. Ankara, Turkey: Ortadogu Teknik Universitesi.

Yildirim, A. \& Simsek, H. (2008). Sosyal bilimlerde nitel arastirma yontemleri [Qualitative research methods in the social sciences]. Ankara, Turkey: Seckin Yayincilik.

Yob, I. M. (2003). Thinking constructively with metaphors. Studies in Philosophy and Education, 22, 127-138.

Zeren, M. G. (2015). Universite ogrencilerinin gozu ile cografya egitimcisi: bir olgubilim arastirmasi [Geography educator with the desire of university students: a research study]. Dogu Cografya Dergisi, 33(20), 189-208.

Zheng, H. (2008). A study of non-English majors' beliefs about English learning: a metaphor appgroach. Philosophy and Humanities Sciences, 4(F), 85-235. 